University of Nebraska - Lincoln

DigitalCommons@University of Nebraska - Lincoln

$10-2010$

\title{
Comment on Richardson: Progressive Federal Taxation Drives Redistribution from Blue to Red States
}

Seth H. Giertz

University of Nebraska-Lincoln, sgiertz2@unl.edu

Follow this and additional works at: https://digitalcommons.unl.edu/econfacpub

Part of the Economic Policy Commons, Public Economics Commons, and the Public Policy Commons

Giertz, Seth H., "Comment on Richardson: Progressive Federal Taxation Drives Redistribution from Blue to Red States" (2010). Economics Department Faculty Publications. 68.

https://digitalcommons.unl.edu/econfacpub/68

This Article is brought to you for free and open access by the Economics Department at DigitalCommons@University of Nebraska - Lincoln. It has been accepted for inclusion in Economics Department Faculty Publications by an authorized administrator of DigitalCommons@University of Nebraska - Lincoln. 


\section{Comment on Richardson: Progressive Federal Taxation Drives Redistribution from Blue to Red States}

\section{SETH H. GIERTZ}

Dear Editors:

Tn a recent issue of The Economists' Voice, 1 Gary Richardson argues that Republicans tend to oppose income redistribution, yet, when in power-especially after the 1994 "Republican revolution"—redistribution from Democrats to Republicans has steadily increased. Unfortunately, Professor Richardson's analysis falls short in a couple of respects.

Richardson argues that "it is tax changes that appear to explain the majority of the rise in net return to Republicans." I agree that taxes are the key driver of the observed pattern, however, for very different reasons. Three factors go a long way in explaining the increasing return to federal tax dollars for red states:

1. Incomes are generally much lower in red states than in blue states.

2. The federal tax system remains highly progressive.

3. Incomes have diverged in recent decades-especially at the very top of the income distribution. This more than offsets decreases in progressivity resulting from the Bush tax cuts.

Ranking states by 2005 per capita income shows that the five richest states are all Democratic strongholds. Of the 17 richest states, only three voted Republican in 2008. At the other end of the spectrum, the poorest eight states are all Republican 
strongholds. Of the poorest 17 states, 15 voted Republican in 2008. ${ }^{1}$

The Congressional Budget Office shows that the federal tax system is quite progressive. From 1979 to 2005, the share of taxes has always increased substantially with income. This is why the "rich" blue states fare so poorly and the "poor" red states make out so well.

The patterns Professor Richardson highlights are not driven by Republican legislators redistributing income from Democrats, but are mainly the product of the correlation between the voting behavior of states and their per capita incomes, the continued progressivity of the U.S. federal tax system and the widening of the income distribution.

Seth H. Giertz

University of Nebraska-Lincoln

\section{NOTES}

1. See "Maps of the 2008 US presidential election results," http://www-personal.umich.edu/ mejn/ election/2008. The analysis changes only slightly if states are classified by the average voting patterns over several of the most recent elections, instead of classifying states based on 2008 presidential election results.

\section{REFERENCES AND FURTHER READING}

Congressional Budget Office (December 2008) "Historical Effective Tax Rates, 1979 to 2005," Letter to the Honorable Max Baucus. Washington, D.C.: Congressional Budget Office. Available at: http://www.cbo. gov/ftpdocs/98xx/doc9884/12-23-EffectiveTaxRates Letter.pdf.

Piketty, Thomas and Emmanuel Saez (2003) "Income Inequality in the United States, 1913-1998," Quarterly Journal of Economics, 118: 1-39. Available at: http://www.nber. org/papers/w8467.

Richardson, Gary (2009) "The Truth about Redistribution: Republicans Receive, Democrats Disburse," The Economists' Voice, 6(10): Art. 3. Available at: http://www.bepress.com/ ev/vol6/iss10/art3. 